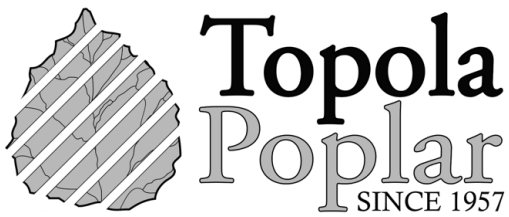

OPEN ACCESS

DOI: $10.5937 /$ topola2101005S

UDC: $630 * 42: 551.583(497.6$ Republika Srpska)

Original scientific paper

\title{
The impact of climate change on the growth of European beech at optimal altitudes in the Republic of Srpska
}

\author{
Stefan Stjepanović ${ }^{*}{ }^{*}$, Boban Miletić ${ }^{1}$, Branislav Drašković $^{1}$, Vesna Tunguz ${ }^{1}$ \\ 1 University of East Sarajevo, Faculty of Agriculture, Istočno Sarajevo, Republic of Srpska (Bosnia and \\ Herzegovina) \\ * Corresponding author: Stefan Stjepanović; E-mail: stefan.stjepanovicuis@gmail.com
}

Received: 22 Dec 2020; Revised: 26 Jan 2021; Accepted: 30 Apr 2021

\begin{abstract}
Many studies have shown that small climate changes can strongly affect the forest trees growth rate, many times causing changes in species habitats. In general, drought is mentioned as the main problem, so it is necessary to carry out its identification and quantification to investigate its effects on forests in Republic of Srpska. This study aims to analyse the relationship between the growth of European beech (Fagus sylvatica L.) at optimal altitudes in the Republic of Srpska and its climate characteristics represented by the Forestry Aridity Index (FAI) and Ellenberg's climate quotient (EQ) for 1950-2015 timespan. FAI and EQ were calculated using climate data (temperature and precipitation) extracted from a gridded dataset (E-OBS). Sampling was carried out in two localities near Vlasenica and Mrkonjić Grad at 1050 and 1030 meters above sea level (m a.s.l.), sampling the cores from 15 dominant trees at each locality. Using the Pearson Correlation Analysis, a negative impact on tree rings width (TRW) with rising index values was identified. This is especially pronounced for the index values of the year prior to the ring formation. In general, stronger negative correlations between TRW and EQ are found for the locality near Mrkonjić Grad, while FAI index showed a greater negative impact on TRW for the locality near Vlasenica.
\end{abstract}

Keywords: European beech, Fagus sylvatica, radial growth, climate change, aridity index.

\section{Introduction}

The term climate change can be understood as significant changes in temperature, precipitation, wind, and other climatic elements that are evident in at least 30 years caused either by natural or human action (Whitlock, 2012). Such changes can have positive effects (prolongation of the vegetation period, an increase of moisture utilization efficiency, increased $\mathrm{CO}_{2}$ assimilation) and negative effects on forest ecosystems (change of tree species range, decrease of growth and vitality, increased pathogens and insects infestation, increased number of fires, windbreaks, etc.). However, forests as large producers of $\mathrm{O}_{2}$ and consumers of $\mathrm{CO}_{2}$ affect the climate, but also climate and climate change affect the growth and vitality of forests (Allen et al. 2010; Stjepanović et al. 2015). The stability of forest ecosystems under changing climatic conditions depends on the adaptation potential of individual tree species (Scharnweber et al. 2011). How European beech (Fagus sylvatica L.) will respond to climate change is of 
paramount importance for European and local forestry, as it currently covers more than $2 / 3$ of the forest area of Central Europe (Bohn et al. 2003), and it is one of the most important forest tree species in Bosnia and Herzegovina, both economically and ecologically (Ballian et al. 2012). Campioli et al. (2012), founded that there will be a significant reduction in the growth of beech trees if the drought occurs in the early phase of the vegetation period than if the dry periods occur before the end of the vegetation period. According to different climate scenarios, the number and duration of droughts are increasing, so in the future, we can expect the boundaries of the beech stands to move to higher altitudes (Von Wuehlisch, 2004), i.e. to retreat to the remaining climatically suitable areas for their development. Some authors considered that European beech will move its area according to northern regions (Jump et al. 2006; Piovesan et al. 2008; Bolte et al. 2010), whereby, according to Hanewinkel et al. (2013) such shifts of forest trees areas has already been noticed. For these reasons, it is of utmost importance to perform drought identification and quantification, with the use of a drought index appearing to be the simplest method for such analysis. The scale in relation to which drought is determined and its intensity should be presented and linked to the specific consequences that may occur. Given the differences in the definition of drought, it is very difficult to find a universal index. Also, due to the complexity of the drought, no index can describe the drought completely (Rajić and Zemunac, 2017). Since temperatures and precipitation are the most commonly used climatic factors that determine such changes at the global, regional, and local levels (Casalegno et al. 2011), to quantify the impact of climate change on beech growth, we used climate indices calculated based on these climate factors.

\section{Material and methods}

Considering that beech populations growing in their optimum altitude levels are not as sensitive to climate change as populations growing at the boundaries of their ranges (Thuiller et al. 2005) and since such stands are the best representative of productive capacities of beech stands in Bosnia and Herzegovina (in the Republic of Srpska, as well), they are selected as an object of our analysis. For this purpose, two localities were selected, each located within a separate climate zone (province) (Figure 1).

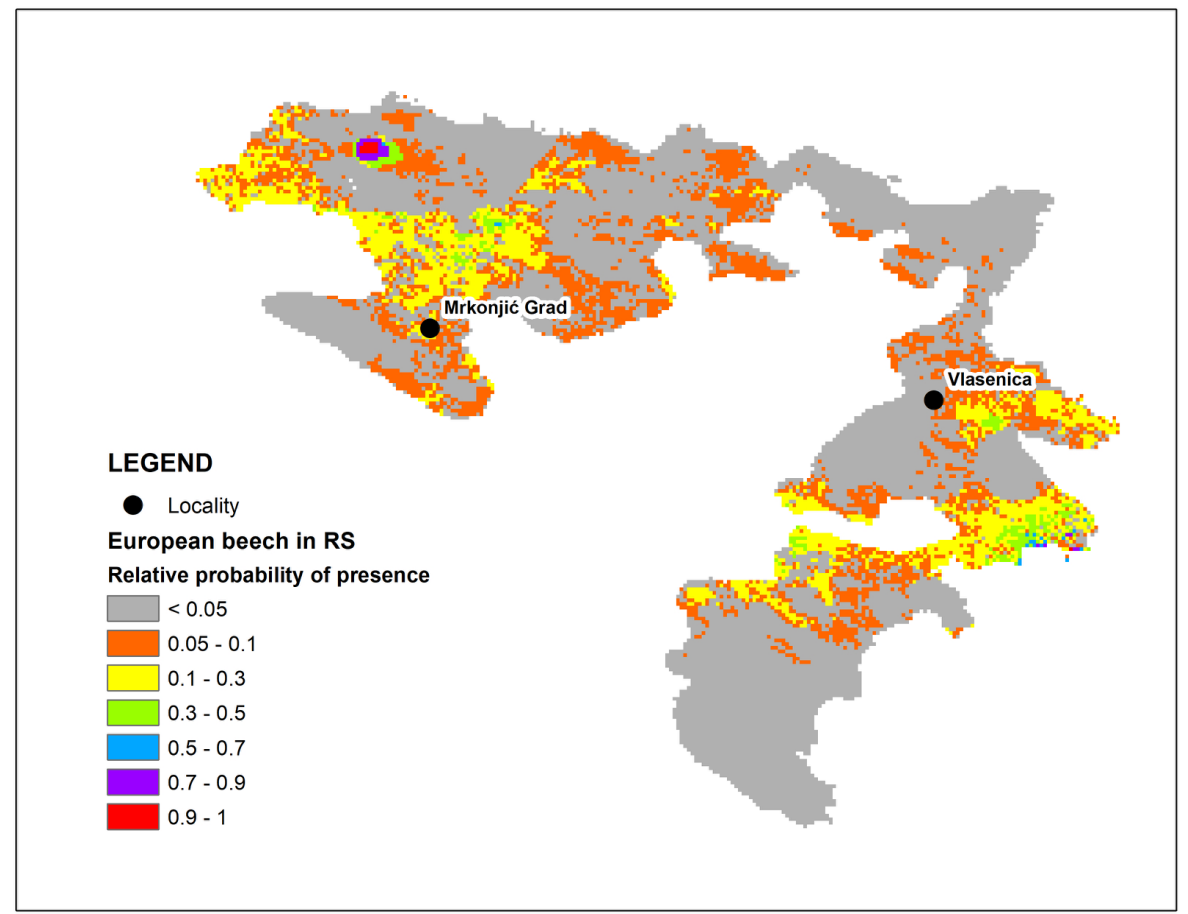

Figure 1. European beech (Fagus sylvatica L.) relative probability of presence (de Rigo et al. 2016) and investigated localities. 
For the research, a sample of 15 European beech (Fagus sylvatica L.) trees was taken in pure stands of mountain beech forests (Fagetum montanum) at $1050 \mathrm{~m}$ a.s.l. on locality Vlasenica (Moesian province) and at $1030 \mathrm{~m}$ a.s.l. on locality Mrkonjić Grad (Illyrian province). Fritts (1976) was found that the majority of the sample should be 15 dominant trees in order to satisfy the principle of replication, i.e. to cross-date to avoid the possibility of a lack of tree ring or the existence of a false tree ring. The dominant trees were included in the sample, because they provide the most reliable climatic data and more accurately reflect the growth dynamics of the entire stand (Komin, 1970). With Presler's borer at chest height $(\mathrm{h}=1.30 \mathrm{~m})$, each tree was drilled to the center on two crossed sides to obtain bits that determine the width of the rings. The screws were dried at room temperature, then glued to the grooved slats, tangentially cut and sanded with sandpaper to make the growth rings as visible as possible. The samples thus prepared were scanned in high resolution using the ATRICS system (Levanič, 2007), and then the width of the rings was measured using Coo Recorder v.7.3 software and C Dendro v.7.3 (Larsson, 2014). Chronologies were crossed and synchronized in PAST-5 ${ }^{\text {nd }}$ dendrochronological software, using both on-screen visual comparisons and statistical parameters. Individual year widths were standardized using ARSTAN (Cook and Krusic, 2005) to eliminate agerelated trends and eliminate ecosystem factors from chronology (Alestalo, 1971).

Mean monthly climate data were taken from the E-OBS climate database (Cornes et al. 2018) for the analyzed localities. According to the equation (1), Forest Aridity Index (FAI) represents the ratio of the average temperature in July and August and the sum of precipitation from May to July and the sum of precipitation in July and August (Führer et al., 2011).

$$
F A I=\frac{T_{V I I-V I I}}{P_{V-V I I}+P_{V I I-V I I I}} \times 100(1)
$$

Ellenberg's climate quotient (EQ) is defined by a simple equation (2), in which mean temperature of the warmest month $\left({ }^{\circ} \mathrm{C}\right)$ is divided by the annual sum precipitation $(\mathrm{mm})$ and multiplied by 1000 .

$$
E Q=\left(T_{\text {max }} / P_{\text {annual }}\right) \times 100
$$

The relationship between tree rings width (TRW) and climate indices (FAI and EQ) in the 19512015 timespan was analyzed using Pearson's correlation from "stats" package in R statistical environment (R Development Core Team, 2020).

\section{Results and discussion}

In general, we found stronger correlations between TRW with FAI and EQ values a year prior to the ring formation, compared to the FAI and EQ values during the year of the ring formation (Table 1).

Table 1. Pearson's correlation between tree rings width (TRW) and climate indices: Ellenberg's climate quotient (EQ) and Forest Aridity Index (FAI).

\begin{tabular}{ccccc}
\hline \multirow{2}{*}{$\begin{array}{c}\text { Investigated } \\
\text { locality }\end{array}$} & \multicolumn{2}{c}{ EQ } & \multicolumn{2}{c}{ FAI } \\
\cline { 2 - 5 } & $\begin{array}{c}\text { Year prior the } \\
\text { ring formation }\end{array}$ & $\begin{array}{c}\text { Year of the } \\
\text { ring formation }\end{array}$ & $\begin{array}{c}\text { Year prior the } \\
\text { ring formation }\end{array}$ & $\begin{array}{c}\text { Year of the } \\
\text { ring formation }\end{array}$ \\
\hline Vlasenica & $-0.38^{* *}$ & $-0.30^{*}$ & $-0.47^{* * *}$ & $-0.29^{*}$ \\
Mrkonjić Grad & $-0.36^{* *}$ & $-0.26^{*}$ & -0.24 & -0.14 \\
\hline
\end{tabular}

Significance level: ${ }^{*} \mathrm{p}<0.05 ;{ }^{* *} \mathrm{p}<0.01 ;{ }^{* * *} \mathrm{p}<0.001$.

This case has been also observed in Serbia for European beech, Scots pine, Austrian oak, Pedunculate oak (Stojanović et al. 2018), and Black pine (Stajić and Kazimirović, 2018), as the highest correlation are found between TRW and cumulative precipitation for approximately a year prior to the 
ring formation. Previous autumn and winter precipitation are known to boost tree-ring formation in several Mediterranean species, for example, Quercus ilex L. and in Quercus cerris L. (e.g. Campelo et al. 2010; Di Filippo et al. 2010). Based on the results of several studies, Vannoppen (2018) concluded that the negative effect of the previous year drought (in our case expressed by FAI and EQ indices) on radial growth (TRW) can be explained by the dependency of the current year growth on the carbohydrate reserve. The only exceptions to this are the results obtained for the Mrkonjić Grad locality, as statistically significant correlations between the TRW and the FAI values a year prior or during the year of the ring formation are not found in this case. On the contrary, this is not the case with EQ, as statistically significant correlations are obtained for both cases. As the great difference between FAI and EQ indices lies in the time-defined type of the precipitation taken into account for its calculations, this case particularly can be explained by a study conducted by Stjepanović (2018) for the named locality. The mentioned author found significant negative correlations with precipitation during the winter period (January and February) in the year of the ring formation. Similar research in the Czech Republic also shown that TRW is negatively correlated with winter (January) precipitation in the year of the ring formation (Remeš et al. 2015). This is very important as autumn and winter precipitation are not taken into account when calculating the FAI index. The lack of statistically significant impact of FAI index on TRW can be explained by different climate characteristics of the climate zones (provinces) in which the investigated forests are located. According to Stefanović et al. (1983) western Illyrian province is more humid in relation to Moesian. According to data obtained from the E-OBS climate database (Cornes et al. 2018), the largest difference between these two localities lies in the distribution of precipitation during the year. At the locality Mrkonjić Grad, higher amounts of precipitation were found during autumn and winter (November $122 \mathrm{~mm}$ and December $106 \mathrm{~mm}$ ), while at the locality Vlasenica most precipitation falls during the vegetation period (May $86 \mathrm{~mm}$, June $94 \mathrm{~mm}$ ). The minimum amount of precipitation at the Vlasenica locality was determined in January and February $(56 \mathrm{~mm})$, while at the Mrkonjić Grad locality it was determined in July $(58 \mathrm{~mm})$. The warmest months at both sites were July and August. At the Mrkonjić Grad locality, the average air temperature in the warmest months was $18.2^{\circ} \mathrm{C}$, and at the Vlasenica locality $17.3^{\circ} \mathrm{C}$. As different populations of European beech are not adapted to the same climatic conditions (Horváth and Mátyás, 2016), we can assume that beech stands in these two localities belong to different populations.

\section{Conclusions}

Based on the obtained results, it can be concluded that the greatest impact on TRW have the climatic characteristics of the year prior to the ring formation. It is important to emphasize that beech stands in both localities showed specific responses to climate change, which is especially pronounced in the Mrkonjić Grad locality. Unlike the Vlasenica locality, no statistically significant relationship was found between the FAI and the tree rings width for this locality. Nevertheless, the actual existence of differences between the analyzed beech stands at both localities needs to be confirmed by provenance tests in some subsequent research.

\section{References}

1. Alestalo, J. (1971): Dendrochronological interpretation of geomorphic processes. Fennia 105: 133-140.

2. Allen, C., Macalady, A., Chenchouni, H., Bachelet, D., McDowell, N., Vennetier, M., Kitzberger, T., Rigling, A., Breshears, D., Hogg, T., Gonzalez, P., Fensham, R., Zhang, Z., Castro, J., Demidova, N., Lim, J., Allard, G., Running, S., Semerci, A., Cobb, N. (2010): A global overview of drought and heat-induced tree mortality reveals emerging climate change risks for forests. Forest Ecology and Management 259: 660-684.

3. Ballian, D., Bogunić, F., Mujezinović, O., Kajba, D. (2012): Genetska diferencijacija obične bukve (Fagus sylvatica L.) u Bosni i Hercegovini. Šumarski list 136(11-12): 587-595. 
4. Bohn, U., Gollup, G., Hettwer, C., Neuhauslova, Z., Schluter, H. (2003): Map of the natural vegetation of Europe, scale 1:2.5 million. Federal Agency for Nature Conservation, Bonn-Bad Godesberg.

5. Bolte, A., Hilbrig, L., Grundmann, B., Kampf, F., Brunet, J. and Roloff, A. (2010): Climate change impacts on stand structure and competitive interactions in a southern Swedish spruce-beech forest. European Journal of Forest Research 129: 261-276.

6. Budeanu, M., Petritan, A. M., Popescu, F., Vasile, D., and Tudose, N. C. (2016): The resistance of European beech (Fagus sylvatica) from the eastern natural limit of species to climate change. Notulae Botanicae Horti Agrobotanici Cluj-Napoca 44(2): 625-633

7. Campelo, F., Nabais, C., Gutiérrez, E., Freitas, H., García-González, I. (2010). Vessel features of Quercus ilex L. growing under Mediterranean climate have a better climatic signal than treering width. Trees 24(3): 463-470.

8. Campioli, M., Vincke, C., Jonard, M., Kint, V., Demaree, G., Ponette, Q. (2012): Current status and predicted impact of climate change on forest production and biogeochemistry in the temperate oceanic European zone: review and prospects for Belgium as a case study. Journal of Forest Research 17: 1-18.

9. Casalegno, S., Amatulli, G., Bastrup-Birk, A., Houston Durrant, T., Pekkarinen, A. (2011): Modelling and mapping the suitability of European forest formations at 1-km resolution. European Journal of Forest Research 130: 971-981.

10. Cook, R.E., Krusic, J.P. (2005): Program ARSTAN - A tree-ring standardization program based on detrending and autoregressive time series modeling, with interactive graphics. Tree-Ring Laboratory, Lamont Doherty Earth Observatory of Columbia University Palisades, NY.

11. Cornes, R., van der Schrier, G., van den Besselaar, E.J.M., Jones, P.D. (2018): An ensemble version of the E-OBS temperature and precipitation datasets. Journal of Geophysical Research Atmosspheres 123(17): 9391-9409.

12. Di Filippo, A., Alessandrini, A., Biondi, F., Blasi, S., Portoghesi, L., Piovesan, G. (2010): Climate change and oak growth decline: Dendroecology and stand productivity of a Turkey oak (Quercus cerris L.) old stored coppice in Central Italy. Annals of Forest Science 67(7): 706-706.

13. Fritts, H.C. (1976): Tree Rings and Climate. Academic Press, New York.

14. Führer, E. (2010): Tree growth and the climate (in Hungarian). “Klíma-21" Füzetek. Springer. Budapest. 61: 98-107.

15. Führer, E., Horváth, L., Jagodics, A., Machon, A., Szabados, I. (2011): Application of new aridity index in Hungarian forestry practice. Időjárás 115(3): 205-216.

16. Hanewinkel, M., Cullmann, D.A., Schelhaas, M.J., Nabuurs, G.J., Zimmermann, N.E. (2013): Climate change may cause severe loss in the economic value of European forest land. Nature Climate Change 3(3): 203.

17. Horváth, A., Mátyás C. (2016): The decline of vitality caused by increasing drought in a beech provenance trial predicted by juvenile growth. South-East European Forestry 7(1): 21-28.

18. Jahn, G. (1991): Temperate deciduous forests of Europe. In: Röhrig, E., Ulrich, B. (eds). Ecosystems of the world. Temperate deciduous forests, Vol. 7. Elsevier, London. pp. 377-502.

19. Jump, A.S., Hunt, J.M., Peñuelas, J. (2006): Rapid climate change-related growth decline at the southern range edge of Fagus sylvatica. Global Change Biology 12: 2163-2174.

20. Komin, G.E. (1970): Cyclicity in Dynamics of Pine Forest Stand in West Siberia, hv. Sib. Otd. Acad. Sc. USSR, Ser. Biol. Med. 3: 36-44.

21. Larsson, L. (2014): Coo Recorder and C dendro programs of the Coo Recorder/ C dendro package version 7.7. Available online: http://www.cybis.se/forfun/dendro (accessed on 3 January 2014).

22. Levanič, T., (2007): ATRICS - A new system for image acquisition in dendrochronology. TreeRing Research 63(2): 117-122. 
23. Piovesan, G., Biondi, F., Di Filippo, A., Alessandrini, A., Maugeri, M. (2008): Drought-driven growth reduction in old beech (Fagus sylvatica) forests of the central Apennines, Italy. Global Change Biology 14(6): 1265-1281.

24. R Core Team (2020): R: A language and environment for statistical computing. R Foundation for Statistical Computing, Vienna, Austria.

25. Rajić, M., Zemunac, R. (2017): Poređenje različitih metoda za ocenu suše na području Južne Bačke. Letopis naučnih radova 42(1): 68-76.

26. Remeš, J., Bílek, L., Novák, J., Vacek, Z., Vacek, S., Putalová, T., Koubek, L. (2015): Diameter increment of beech in relation to social position of trees, climate characteristics and thinning intensity. Journal of Forest Science 61(10): 456-464.

27. Scharnweber, T., Manthey, M., Criegee, C., Bauwe, A., Schröder, C., Wilmking, M. (2011): Drought matters-declining precipitation influences growth of Fagus sylvatica L. and Quercus robur L. in north-eastern Germany. Forest Ecology and Management 262(6): 947-961.

28. Stajić, B., Kazimirović, M. (2018): Uticaj temperature vazduha i padavina na prirast crnog bora (Pinus nigra JF Arnold): Studija slučaj asa područja planine rudnik. Glasnik Sumarskog fakulteta 118: 143-164.

29. Stefanović, V., Beus, V., Burlica, Č., Dizdarević, H., Vukorep, I. (1983): Ekološko vegetacijska rejonizacija Bosne i Hercegovine, Šumarski fakultet u Sarajevu, Posebna izdanja br. 17, Sarajevo.

30. Stjepanović, S., Stojanović, D., Matović, B. (2015): Response of trees on climate extremes in uneven-aged European beech stand. International Journal of Crop Science and Technology 1 (2): $42-46$.

31. Stjepanović, S. (2018): Uticaj klime na rast i vitalnost stabala u zavisnosti od horizontalnog i vertikalnog rasprostranjenja bukovih šuma. Doktorska disertacija. Univeruitet u Novom Sadu. Poljoprivredni fakultet.

32. Stojanović, D., Levanič, T., Matović, B., Stjepanović, S., Orlović, S. (2018): Growth response of different tree species (oaks, beech and pine) from SE Europe to precipitation over time. Dendrobiology 79: 97-110.

33. Thuiller, W., Lavorel, S., Araújo, M.B. (2005): Niche properties and geographical extent as predictors of species sensitivity to climate change. Global Ecology and Biogeography 14(4): 347357.

34. Vannoppen, A. (2018). Patterns and trends in growth of beech and oak. Does biodiversity improve the resilience of forests to environmental change? Arenberg Doctoral School Faculty of Bioscience Engineering, $\mathrm{PhD}$

35. Vlăduț, A., Nikolova, N., Licurici, M. (2017): Influence of climatic conditions on the territorial distribution of the main vegetation zones within Oltenia Region, Romania, Muzeul Olteniei Craiova. Oltenia. Studii şi comunicări. Ştiinţele Naturii 33(1): 154-164.

36. Von Wuehlisch, G. (2004): Series of International Provenance Trials of European Beech. Proceedings from the 7th International Beech Symposium IUFRO Research Group 1.10.00 "Improvement and Silviculture of Beech". 10-20 May 2004, Tehran, Iran. p. 135-144.

37. Whitlock, L. (2012): Regional Climate Vulnerability Assessment. South East European Forum on Climate Change Adaptation.

38. de Rigo, D., Caudullo, G., San Miguel-Ayanz, J. (2016): Distribution map of Fagus sylvatica (2006, FISE, C-SMFAv0-3-2). European Commission, Joint Research Centre (JRC) [Dataset] PID: http://data.europa.eu/89h/21012c45-0433-41d6-910e-24a2e72cf35a 